\title{
PHYSICAL, CHEMICAL AND SENSORY ATTRIBUTES OF FRUITS OF TEN MANGO VARIETIES GROWN UNDER ORGANIC PRODUCTION SYSTEM ${ }^{1}$
}

\author{
RONIELLI CARDOSO REIS ${ }^{2 *}$, ELISETH DE SOUZA VIANA ${ }^{2}$, NELSON FONSECA $^{2}$, JAMILLE MOTA ALMEIDA $^{3}$, \\ JORGE ANTÔNIO DE ANDRADE RODRIGUES FILHO ${ }^{3}$, IOHANA SCARLET ALMEIDA GUEDES ${ }^{3}$
}

\begin{abstract}
This study aimed to assess the physical, chemical, and sensory attributes of mango varieties grown under the organic farming. Fruits from ten varieties of mango grown under the organic system in the Chapada Diamantina region, BA, Brazil, were assessed. The following physical and chemical characteristics were assessed: fruit mass, pulp yield, pulp color $\left(\mathrm{L}^{*}, \mathrm{C}^{*}\right.$, and $\left.\mathrm{h}^{*}\right)$, soluble solids (SS), titratable acidity (TA), total carotenoids, and ascorbic acid. The sensory acceptance test was performed with 50 consumers using the nine-point structured hedonic scale and the attributes acidity, sweetness, and firmness of the pulp were assessed using the just-about-right scale. Differences among the varieties of mango grown under the organic production system were observed for physical, chemical and sensory attributes. The varieties showed a percentage of pulp equal or above $60 \%$, which makes them more suitable for processing. According to the PCA analysis, the characteristics soluble solids, total carotenoids, fruit mass, titratable acidity, $\mathrm{h}^{*}$ and $\mathrm{L}^{*}$ were considered the most important to differentiate the mango varieties evaluated. Ubá and Beta varieties had the highest levels of SS, while Favo de Mel was characterized by the highest values of TA and L*. The varieties Favo de Mel, Palmer, Surpresa, Juazeiro 2, Imperial and Joa had fruits with higher mass and $\mathrm{h}^{*}$ values and the varieties Amrapali and Roxa Embrapa 141 had the highest levels of total carotenoids. Imperial, Palmer, Beta and Joa varieties were the most accepted for all sensory attributes.
\end{abstract}

Keywords: Mangifera indica L. Cultivars. Principal component analysis. Bioactive compounds.

\section{ATRIBUTOS FÍSICOS, QUÍMICOS E SENSORIAIS DE FRUTOS DE DEZ VARIEDADES DE MANGA CULTIVADAS NO SISTEMA ORGÂNICO DE PRODUÇÃO}

\begin{abstract}
RESUMO - O objetivo desse trabalho foi avaliar os atributos físicos, químicos e sensoriais de variedades de manga cultivadas no sistema orgânico de produção. Foram avaliados frutos de dez variedades de manga cultivadas no sistema orgânico, na região da Chapada Diamantina, BA. As seguintes características físicas e químicas foram avaliadas: comprimento, largura, massa, rendimento em polpa, cor da polpa ( $\left.\mathrm{L}^{*}, \mathrm{C}^{*} \mathrm{e} \mathrm{h}^{*}\right)$, sólidos solúveis (SS), acidez titulável (AT), carotenoides totais (CT) e ácido ascórbico. O teste de aceitação sensorial foi realizado por 50 consumidores utilizando a escala hedônica estruturada de nove pontos e os atributos acidez, doçura e firmeza da polpa foram avaliados utilizando a escala do ideal. Diferenças entre as variedades foram observadas para algumas características físicas, químicas e atributos sensoriais. As variedades de manga apresentaram rendimento de polpa igual ou superior a $60 \%$, sendo adequadas para o processamento. De acordo com a análise de componentes principais (ACP) os teores de sólidos solúveis, carotenoides totais, massa do fruto, acidez titulável, $h^{*}$ e $L^{*}$ foram as características mais importantes para diferenciar as variedades avaliadas. As variedades Ubá e Beta apresentaram os maiores teores de SS, enquanto a Favo de Mel caracterizou-se pelos maiores valores de AT e L*. As variedades Favo de Mel, Palmer, Surpresa, Juazeiro 2, Imperial e Joa apresentaram frutos com maiores massa e valores de $h^{*}$ e as variedades Amrapali e Roxa Embrapa 141 apresentaram os maiores teores de carotenoides totais. As variedades Imperial, Palmer, Beta e Joa foram as mais aceitas para todos os atributos sensoriais.
\end{abstract}

Palavras-chave: Mangifera indica L. Cultivares. Análise de componentes principais. Compostos bioativos.

\footnotetext{
${ }^{*}$ Corresponding author

${ }^{1}$ Received for publication in $03 / 30 / 2020$; accepted in $12 / 16 / 2020$.

Paper extracted from the research project Development of organic production systems for tropical fruits.

${ }^{2}$ Embrapa Cassava and Fruits, Empresa Brasileira de Pesquisa Agropecuária, Cruz das Almas, BA, Brazil; ronielli.reis@embrapa.br ORCID: 0000-0003-0475-3619, eliseth.viana@embrapa.br - ORCID: 0000-0003-4343-6536, nelson.fonseca@embrapa.br - ORCID: 0000-0001-8415-950X.

${ }^{3}$ Faculdade Maria Milza, Governador Mangabeira, BA, Brazil; jamille jma@hotmail.com - ORCID: 0000-0002-3786-2988, jorgefilho548@gmail.com - ORCID: 0000-0002-7266-256X, iohanascarlet@hotmail.com - ORCID: 0000-0003-3035-921X.
} 


\section{INTRODUCTION}

Demand for food produced under the organic system has been driven by increased consumer awareness and concern for food quality and safety, as well as environmental protection (CARDOSO et al., 2011).

The area occupied by organic agriculture between 1999 and 2017 increased from 11 to 69.8 million hectares, with Oceania being the continent with the largest area, accounting for 35.65 million hectares. In Brazil, there is approximately 1.14 million hectares, which represents only $0.4 \%$ of the total agricultural area (FIBL, 2020).

Mango (Mangifera indica L.) is one of the most important tropical fruit trees in the world due to its high yield, high consumption, and excellent nutritional value (NTSOANE et al., 2019). Mango fruits have attractive color, pleasant aroma and taste, and are rich in bioactive compounds such as vitamin $\mathrm{C}$, carotenoids, and polyphenols, contributing to antioxidant activity (SIVAKUMAR; JIANG; YAHIA, 2011; LIU et al., 2013).

Worldwide there are over 1000 mango varieties that are grown on an area of 3.7 million hectares, with predominance of the commercial cultivars Tommy Atkins, Haden, Ataulfo, Kent, Keitt, and Alphonso (GENTILE et al., 2019; LAWSON et al., 2019). Brazil recorded in 2017 a mango production of above one million tons, with the state of Bahia being the largest producer, with 438,000 tons harvested in an area of 23,000 hectares (IBGE, 2019).

Fruit quality is measured based on appearance, texture, aroma, taste, nutritional content, and chemical composition, which can vary according to genotype, management practices, climate, and maturity stage (GENTILE et al., 2019).

Assessing these attributes is essential to assist in the choice of the final product, which can be destined for fresh consumption or industrialization. In general, the most suitable varieties for industrial purposes are those with high pulp yield, high soluble solids content, and few fibers (RUFINI et al., 2011). On the other hand, characteristics such as color, aroma, taste, and texture are the most important for fresh consumption. In addition, aspects related to the nutraceutical value of fruits have also been considered due to the increased interest of consumers in products that have health benefits.

In this context, some research has been conducted in several regions of the world, such as China (LIU et al., 2013), Himalayas (BAKSHI et al., 2013), Brazil (CARVALHO et al., 2004; BATISTA et al., 2015), Thailand (RUMAINUM et al., 2018), Pakistan (SABIR et al., 2018), and Mediterranean region (GENTILE et al., 2019). However, they have assessed genotypes from commercial areas or have not mentioned cultivation systems employed. Only the study conducted by Gentile et al. (2019) assessed fruit from genotypes grown under the organic system.

Thus, this study aimed to assess the physical, chemical, and sensory characteristics of fruits of ten mango varieties grown under the organic production system.

\section{MATERIAL AND METHODS}

Mango cultivation was carried out in the municipality of Lençóis, in the Chapada Diamantina region, located in the state of Bahia, Brazil, at the geographic coordinates $12^{\circ} 36^{\prime} 29.4^{\prime \prime} \mathrm{S}$ and $41^{\circ} 21^{\prime}$ $14.6^{\prime \prime} \mathrm{W}$, and altitude of $400 \mathrm{~m}$. The region is characterized by the tropical climate, with a dry season, average annual precipitation of 1,186 $\mathrm{mm}$ concentrated from November to April and average annual temperature ranging from 20 to $29^{\circ} \mathrm{C}$.

Fruits of the mango varieties Amrapali, Beta, Favo de Mel, Imperial, Joa, Juazeiro 2, Palmer, Roxa Embrapa 141, Surpresa, and Ubá were assessed. Spacing between plants was $8 \times 8 \mathrm{~m}$, consisting of 156 plants.ha ${ }^{-1}$. In preparing the soil, liming was carried out to raise the base saturation to $70 \%$ and gypsum was applied (0.5 t / ha), followed by the cultivation of an improving plant (Stylosanthes capitata Vogel). In the planting pit, 18 liters of bovine and sheep manure were used, and castor bean peel (ratio 2: 1: 1) supplemented with natural phosphate of gafsa $(1.0 \mathrm{~kg})$. After planting, topdressing fertilization, weeding around the plants, mowing of the vegetation between the rows keeping it low, and drip irrigation were carried out.

Top-dressing fertilizations were carried out every six months with mixed bovine and caprine manure, proportion 2: 1 (18 L / plant), in addition to 'bokashi' type formulations ( $2.5 \mathrm{~kg} /$ plant) and rock powder $(2.5 \mathrm{~kg} /$ plant $)$. For the preparation of 1.0 ton of 'bokashi' the following amounts were used: $250 \mathrm{~kg}$ of castor bean pie, $150 \mathrm{~kg}$ of forest soil (source of microorganisms), $300 \mathrm{~kg}$ of aged bovine manure, $200 \mathrm{~kg}$ of mylonite calc-silicate rock powder, $50 \mathrm{~kg}$ of natural gafsa phosphate, $20 \mathrm{~kg}$ of micronutrient, $10 \mathrm{~kg}$ of magnesium oxide and $20 \mathrm{~L}$ of sugar cane molasses.

Drip irrigation was applied at a total flow rate of $48 \mathrm{~L} \mathrm{/} \mathrm{plant} \mathrm{/} \mathrm{day.} \mathrm{The} \mathrm{floral} \mathrm{induction} \mathrm{of} \mathrm{the}$ plants was done by applying water deficit for 60 days after the sprouting of the fruiting branches. The return of irrigation occurred when the buds of the branches showed signs of flowering in all varieties.

Fruits were harvested at the ripe stage, with pulp color ranging from orange-yellow to orange, depending on the variety. Fruits were packed in plastic containers and taken to the Laboratory of Food Science and Technology of Embrapa Cassava and Fruits in Cruz das Almas, Bahia, for analysis.

Ten fruits of each variety were assessed for fruit mass and pulp yield. Fruit mass was measured 
using a semi-analytical balance. Pulp yield was obtained by subtracting peel and seed mass from the whole fruit mass, being expressed as a percentage.

For the other analyses, ten fruits of each variety were peeled, the seeds were removed, and the pulp was ground, forming a homogeneous sample. Pulp color was determined using a Konica Minolta CR400 colorimeter, with CIELAB system and D65 illuminant. Coordinates L* (lightness) and chromatic attributes $\mathrm{C}^{*}$ (color saturation/ intensity) and $\mathrm{h} *$ (hue angle) were assessed. Analyses of soluble solids (SS) and titratable acidity (TA) were performed according to the methodology by Instituto Adolfo Lutz (ZENEBON; PASCUET; TIGLEA, 2008), and expressed as g. $100 \mathrm{~g}^{-1}$ pulp. Total carotenoid was determined according to Rodriguez-Amaya and

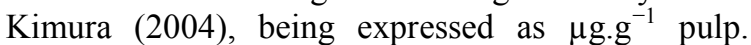
Extraction was performed with acetone, followed by partitioning in petroleum ether and reading on a UVVisible spectrophotometer at $450 \mathrm{~nm}$. Ascorbic acid content was determined by the reaction between ascorbic acid and 2,6-dichlorophenol-indophenol (DCPIP), with subsequent detection in a spectrophotometer at $520 \mathrm{~nm}$, being expressed as $\mathrm{mg} .100 \mathrm{~g}^{-1}$ pulp, according to the procedure described by Oliveira (2010).

The sensory test was performed in individual booths under white light. Fruits were peeled, cut into $25 \mathrm{~g}$ pieces, and served at ambient temperature in disposable white plates properly coded with random three-digit numbers. Each taster received a sample sequential monadically in a balanced complete block design. A glass of mineral water was served to rinse the mouth between evaluations. The acceptance test was performed by 50 consumers using the nine-point structured hedonic scale, with the extremes "dislike extremely" (1) and "like extremely" (9), according to NBR 14141 (MEILGAARD; CIVILLE; CARR, 1999) for attributes color, aroma, flavor, texture, and overall acceptance. In addition to the sensory acceptance test, the tasters evaluated the attributes acidity, sweetness, and firmness of fruit using the just-about-right scale of five points (ROTHMAN; PARKER, 2009). Purchase intention was evaluated using scale of five points ranging from "certainly would buy" and "certainly would not buy". For the sensory tests to be conducted, the study was approved by the Research Ethics Committee and registered under CAAE no. 23109213.9.0000.5556.

Physical, physical-chemical and chemical data were subjected to principal component analysis (PCA) from the correlation matrix, which generated a graphical representation of the evaluated varieties and characteristics. The cluster analyses was also performed using Euclidian distance and UPGA (Unweighted Pair-Group Average) method. All statistical analyses were performed using the STATISCA 7.0 (STATSOFT, 2008) and Genes programs (CRUZ, 1997).

Sensory acceptance data were analyzed by analysis of variance at $5 \%$ probability, and the ScottKnott test was performed at 5\% significance when the F-test was significant. Pearson's linear correlation analysis (R) was also performed between sensory attributes and overall acceptance. The data of the just-about-right scale were shown in a frequency graph.

\section{RESULTS AND DISCUSSION}

A PCA analysis (Figure 1) was performed to globally evaluate the most relevant variables. The first two principal components (PCs) explained $75.3 \%$ of the total variance and were selected for describing mango characteristics. From the cluster analysis, four groups were identified, which can be seen in Figure $1 \mathrm{~A}$.
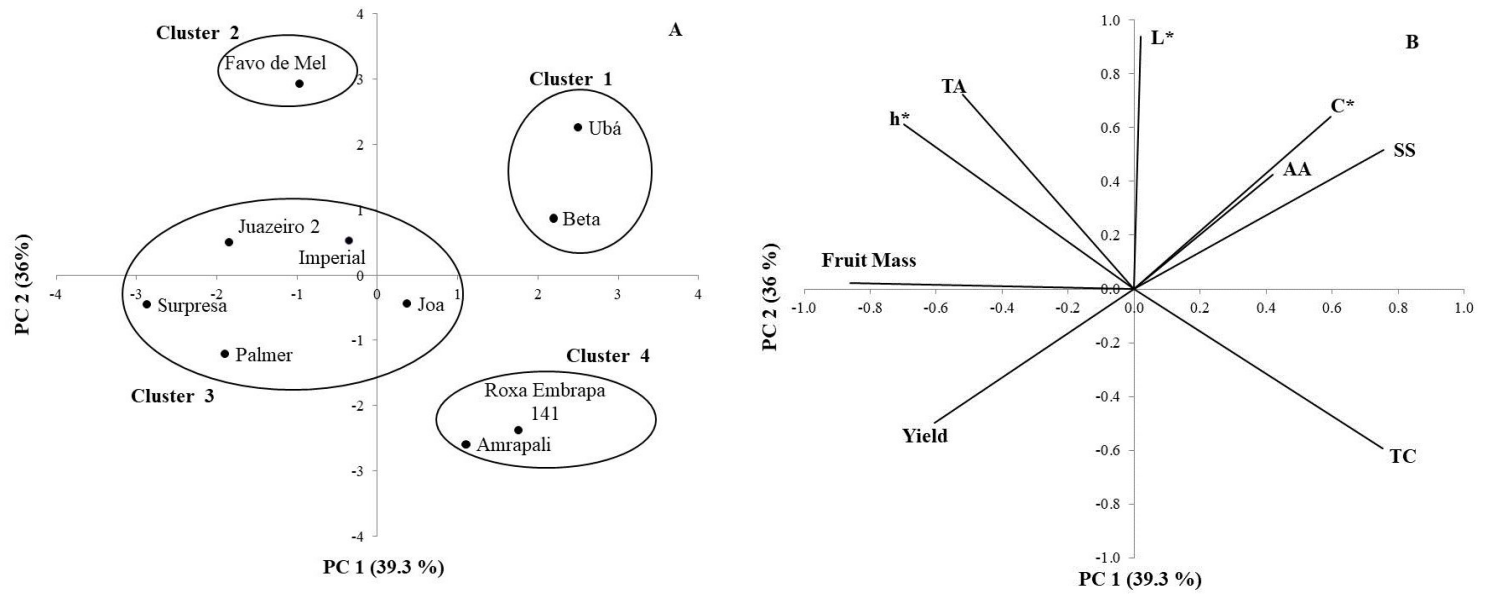

Figure 1. Principal component analysis of physical and chemical characteristics of mango varieties grown under the organic production system. A: spatial separation of the mango varieties. B: correlations between physical and chemical characteristics and the first two principal components (PCs). TA: titratable acidity, SS: soluble solids, TC: total carotenoids, AA: ascorbic acid. 
In Figure $1 \mathrm{~B}$ it is possible to see the characteristics most relevant to separate the groups formed. The first component was highly related to SS (0.75), TC (0.75), fruit mass (-0.86) and $h^{*}(-0.70)$, whereas the second component was highly related to TA $(0.72)$ and $L^{*}(0.94)$ (Figure 1B). The other characteristics showed correlations lower than or equal to 0.65 and hence were not considered relevant to differentiate mango varieties. Liu et al. (2013) assessed different mango genotypes and found that characteristics such as titratable acidity $(0.988), L^{*}(0.963)$, weight $(-0.829)$, soluble solids (0.963), and $\beta$-carotene $(0.965)$ were important for the separation of mango varieties, corroborating the results of this study.

Varieties Roxa Embrapa 141 and Amrapali (cluster 4) were characterized by the highest TC (Figures 1A and 1B). Varieties Ubá and Beta (cluster 1) were mainly characterized by high SS content, while varieties belonging to cluster 2 and cluster 3 showed high fruit mass and $h^{*}$ values. Variety Favo de Mel differed from the others regarding its higher TA and $\mathrm{L}^{*}$ values.

Table 2 shows the average values of physicalchemical characteristics for each group formed by cluster analysis. Cluster 1 (Ubá and Beta) and cluster
4 (Amrapali and Roxa Embrapa 141) had the lowest value of fruit mass. Fruit size and fruit mass are important factors for the fresh fruit market and may determine the market for which the fruit will be destined. Fruit mass between 250 and $600 \mathrm{~g}$ is preferred by the American market, while the European market prefers fruit mass between 300 and $450 \mathrm{~g}$ (OLIVEIRA et al., 2010).

A low variation was observed between clusters regarding pulp yield and all varieties had a percentage of pulp above $60 \%$ (Table 1), which makes them suitable for processing (FOLEGATTI et al., 2002). Carvalho et al. (2004) observed higher pulp yield $(81.8 \%)$ than that observed in the present study for variety Palmer (cluster 3) grown under the conventional production system. However, Bakshi et al. (2013) and Palei et al. (2016) reported lower $(64.74 \%)$ and higher $(87.12 \%)$ percentages of pulp, respectively, for variety Amrapali (cluster 4). High pulp yield in the fruit can reduce processing costs by reducing preparation losses and hence production costs. However, other characteristics should be considered when choosing fruit for industry, such as soluble solids content, fiber, acidity, taste, and pulp color.

Table 1. Physical and chemical characteristics of fruits from different mango varieties produced under the organic system in the Chapada Diamantina region, BA, Brazil.

\begin{tabular}{ccccc}
\hline Characteristics & Cluster 1 & Cluster 2 & Cluster 3 & Cluster 4 \\
\hline Fruit mass (g) & $181.60 \pm 39.90$ & 450.40 & $369.22 \pm 80.11$ & $223.45 \pm 4.65$ \\
Pulp Yield (\%) & $60.71 \pm 1.90$ & 68.79 & $72.34 \pm 2.41$ & $71.98 \pm 0.75$ \\
Soluble solid ( ${ }^{\circ}$ Brix) & $23.39 \pm 0.03$ & 20.87 & $19.18 \pm 1.34$ & $19.58 \pm 1.30$ \\
Titratable acidity $\left(\mathrm{g} .100 \mathrm{~g}^{-1}\right)$ & $0.40 \pm 0.03$ & 0.74 & $0.46 \pm 0.11$ & $0.22 \pm 0.10$ \\
Ascorbic acid $\left({\left.\mathrm{mg} 100 \mathrm{~g}^{-1}\right)}^{\text {) }}\right)$ & $24.74 \pm 6.80$ & 26.06 & $7.51 \pm 2.80$ & $13.99 \pm 7.07$ \\
Carotenoids $\left(\mu \mathrm{g} \mathrm{g}^{-1}\right)$ & $60.35 \pm 12.80$ & 27.67 & $36.07 \pm 12.57$ & $92.33 \pm 2.33$ \\
$\mathrm{~L}^{*}$ & $48.29 \pm 1.81$ & 51.50 & $46.04 \pm 1.48$ & $43.37 \pm 0.64$ \\
$\mathrm{C}^{*}$ & $44.74 \pm 1.60$ & 44.37 & $40.16 \pm 2.34$ & $40.01 \pm 1.94$ \\
$\mathrm{~h}^{*}$ & $80.01 \pm 0.22$ & 85.17 & $83.27 \pm 1.95$ & $72.12 \pm 0.97$ \\
\hline
\end{tabular}

Cluster 1: formed by Ubá and Beta varieties; Cluster 2: formed by Favo de Mel variety; Cluster 3: formed by Palmer, Surpresa, Juazeiro 2, Imperial and Joa varieties; Cluster 4: formed by Amrapali and Roxa Embrapa 141 varieties; L*: lightness; $\mathrm{C}^{*}$ : color saturation/intensity; $\mathrm{h}^{*}$ : hue angle. TA: titratable acidity, SS: soluble solids.

All varieties showed the minimum soluble solids content ( $11^{\circ}$ Brix) for mango pulp and mango juice established by Normative Instruction no. 37 of October 1, 2018 (BRASIL, 2018). Mango pulp of cluster 2 (Favo de Mel) had higher titratable acidity (Table 1). Lower values for titratable acidity (0.15 g. $100 \mathrm{~g}^{-1}$ pulp) and soluble solids (15.3 ${ }^{\circ}$ Brix $)$ were found by Batista et al. (2015) for variety Palmer (cluster 3) grown under the conventional system in the upper-middle São Francisco Valley.

Soluble solids, titratable acidity may vary according to variety, maturity stage, climate, soil, and management practices, factors that justify the differences observed between values of this study and those reported in the literature. Some studies have found an inverse relationship between soil nitrogen concentration and soluble solids content of fruits, and this effect is attributed to the vegetative growth of plants, which reduces the accumulation of sugars in fruit (MDITSHWA et al., 2017). However, few studies have reported management practices and fertilizers used, making it difficult to understand the effect of the production system on the chemical characteristics of fruits.

The ascorbic acid contents ranged from 7.51 (cluster 3) to $26.06 \mathrm{mg} .100 \mathrm{~g}-1$ (cluster 2) (Table 1). Higher values were obtained by Carvalho et al. (2004) for variety Palmer (56.7 mg. $100 \mathrm{~g}^{-1}$ pulp) and Ribeiro et al. (2007) for mango fruit 'Ubá (77.71 mg. $\left.100 \mathrm{~g}^{-1}\right)$. Plants tend to accumulate 
ascorbic acid under oxidative stress, which can be caused by different factors, such as sunlight, herbicides or nitrogen availability (PAOLETTI, 2014). These factors may explain the low ascorbic acid values observed in mangoes assessed in this study, as herbicides cannot be used in organic cultivation, reducing plant stress and, consequently, ascorbic acid production. However, other factors such as climate conditions, maturity stage, postharvest processes, and soil nutrient management (e.g., nitrogen, potassium, phosphorus, and magnesium) influence vitamin $\mathrm{C}$ synthesis (MDITSHWA et al., 2017).

Varieties Amrapali and Roxa Embrapa 141 (cluster 4) had the highest total carotenoid (TC) and Favo de Mel variety had the lowest value. Carvalho et al. (2004) observed carotenoid values of $40 \mu \mathrm{g} \cdot \mathrm{g}^{-1}$ for variety Palmer grown under the conventional system in the São Paulo region, a value similar to that observed in this study. Liu et al. (2013) observed that carotenoid values of four mango varieties ranged from 25.7 (JinHwang) to $61.4 \mu \mathrm{g} . \mathrm{g}^{-1}$ (Keitt), while Gentile et al. (2019) reported a higher variation, with values ranging from 3.69 (Keitt) to $63.91 \mu \mathrm{g} . \mathrm{g}^{-1}$ (Carrie). Factors such as sun exposure during fruiting, genotype, maturity stage, and storage conditions affect carotenoid production (GENTILE et al., 2019) and assist in understanding differences found between mango varieties assessed in this study and those reported in the literature. Some studies have shown that the production system could influence carotenoid accumulation in fruit. According to Paoletti (2014), nitrogen is readily available to plants under conventional systems, increasing chloroplast production within cells. As carotenoid synthesis occurs within chloroplasts, plants with more chloroplasts tend to accumulate more carotenoids, which would lead to high carotenoid contents in fruit growing under the conventional cultivation.

Favo de Mel (cluster 2) was characterized by fruits with lighter pulp color (higher $\mathrm{L}^{*}$ value) than the others (Table 1). Fruits of varieties Amrapali and Roxa Embrapa 141 (cluster 4) showed L* values below 45 , being thus characterized by a slightly darker pulp than the others. The saturation $\left(\mathrm{C}^{*}\right)$ ranged from 40.01 (cluster 4 ) to 44.74 (cluster 1), but this attribute was not considered relevant to differentiate the varieties (Figure 1B). The hue angle $\left(\mathrm{h}^{*}\right)$ ranges from 0 (red), 90 (yellow), 180 (green) to 270 (blue) (RAMALLO; MASCHERONI, 2012). The $\mathrm{h}^{*}$ value ranged from 72.12 (cluster 4) to 85.17 (cluster 2), indicating that, in general, the hue of the pulp of all varieties is between red and yellow. The varieties belonging to clusters 1,2 and 3 are characterized by a yellowish flesh, since the $h$ * values are close to 90. Batista et al. (2015) observed that pulp of variety Palmer grown under the conventional system in the upper-middle São Francisco Valley region showed similar values of $\mathrm{L}^{*}$ (42.95), $\mathrm{C}^{*}(40.11)$ and $\mathrm{h}^{*}\left(89.06^{\circ}\right)$. Variations in the color of mango pulp may occur due to variety and different maturity stages. In this study, varieties were grown under the same conditions and assessed at the same maturity stage, and, therefore, the observed variations are due to the characteristics of each variety.

The sensory acceptance test showed differences among mango varieties for the attributes color, aroma, taste, and overall acceptance (Table 2). No difference was found for texture, which had a mean score of 7.15. Varieties Imperial, Palmer, Beta, and Joa did not differ from each other and were the most accepted regarding all sensory attributes, with an acceptance between the hedonic terms "like moderately" and "like very much."

Table 2. Sensory acceptance of mango varieties grown under the organic production system. Lençóis, BA, Brazil. 2019.

\begin{tabular}{lccccccc}
\hline \multirow{2}{*}{ Variety } & \multicolumn{7}{c}{ Sensory acceptance } \\
\cline { 2 - 8 } & Color & Aroma & Flavor & Texture & Overall & PI $^{\mathrm{a}}$ & $\% \mathrm{AP}^{\mathrm{b}}$ \\
\hline Imperial & $8.0 \pm 0.9 \mathrm{a}$ & $7.4 \pm 1.3 \mathrm{a}$ & $7.7 \pm 1.3 \mathrm{a}$ & $7.3 \pm 1.4 \mathrm{a}$ & $7.6 \pm 1.1 \mathrm{a}$ & 78.0 & 98.0 \\
Palmer & $7.9 \pm 0.8 \mathrm{a}$ & $7.6 \pm 1.2 \mathrm{a}$ & $7.6 \pm 1.3 \mathrm{a}$ & $7.5 \pm 1.2 \mathrm{a}$ & $7.7 \pm 1.0 \mathrm{a}$ & 75.5 & 98.0 \\
Beta & $7.9 \pm 0.9 \mathrm{a}$ & $7.2 \pm 1.4 \mathrm{a}$ & $7.4 \pm 1.5 \mathrm{a}$ & $7.0 \pm 1.3 \mathrm{a}$ & $7.4 \pm 1.0 \mathrm{a}$ & 71.2 & 92.0 \\
Joa & $7.8 \pm 1.0 \mathrm{a}$ & $7.2 \pm 1.3 \mathrm{a}$ & $7.4 \pm 1.5 \mathrm{a}$ & $7.1 \pm 1.7 \mathrm{a}$ & $7.4 \pm 1.5 \mathrm{a}$ & 70.0 & 92.0 \\
Ubá & $7.7 \pm 1.1 \mathrm{a}$ & $6.8 \pm 1.3 \mathrm{~b}$ & $7.0 \pm 1.6 \mathrm{~b}$ & $6.6 \pm 1.6 \mathrm{a}$ & $6.9 \pm 1.6 \mathrm{~b}$ & 68.0 & 87.5 \\
Amrapali & $7.7 \pm 1.3 \mathrm{a}$ & $6.8 \pm 1.4 \mathrm{~b}$ & $7.1 \pm 1.8 \mathrm{~b}$ & $7.1 \pm 1.7 \mathrm{a}$ & $6.9 \pm 1.7 \mathrm{~b}$ & 64.0 & 83.3 \\
Roxa Embrapa & $7.6 \pm 1.5 \mathrm{a}$ & $6.7 \pm 1.5 \mathrm{~b}$ & $6.8 \pm 2.0 \mathrm{~b}$ & $7.3 \pm 1.5 \mathrm{a}$ & $6.9 \pm 1.6 \mathrm{~b}$ & 57.7 & 84.0 \\
141 & $7.6 \pm 1.3 \mathrm{a}$ & $6.9 \pm 1.3 \mathrm{~b}$ & $6.8 \pm 1.3 \mathrm{~b}$ & $7.4 \pm 1.3 \mathrm{a}$ & $6.8 \pm 1.6 \mathrm{~b}$ & 60.8 & 78.0 \\
Surpresa & $7.0 \pm 1.3 \mathrm{~b}$ & $6.2 \pm 1.7 \mathrm{~b}$ & $6.7 \pm 1.7 \mathrm{~b}$ & $6.9 \pm 1.2 \mathrm{a}$ & $6.8 \pm 1.3 \mathrm{~b}$ & 65.4 & 88.0 \\
Juazeiro 2 & $6.7 \pm 1.4 \mathrm{~b}$ & $6.9 \pm 1.4 \mathrm{~b}$ & $7.2 \pm 1.5 \mathrm{a}$ & $7.1 \pm 1.5 \mathrm{a}$ & $6.8 \pm 1.6 \mathrm{~b}$ & 60.0 & 84.0 \\
Favo de Mel & & & & & & &
\end{tabular}

aPurchase intention calculated by summing the terms "certainly would buy" and "probably would buy." bAcceptance Percentage calculated considering the tasters who assigned scores higher than or equal to 6.0 for the attribute overall acceptance. Means followed by different letters in the column differ by the Scott-Knott test at $5 \%$ probability 
Considering the percentage of tasters who assigned scores higher than or equal to 6.0 , the four varieties had approval above $92 \%$ and purchase intention above $70 \%$ (Table 2). Varieties Surpresa, Amrapali, Roxa Embrapa 141, and Favo de Mel were the least approved, with percentages between 78 and $84 \%$, and lower purchase intention (below $64 \%$ ) than the others.

The analysis of linear correlation between sensory attributes and overall acceptance showed that the attributes aroma $(\mathrm{R}=0.90)$, flavor $(\mathrm{R}=0.87)$ and color $(\mathrm{R}=0.70)$ were the most important for the acceptance of mangoes. The texture showed no significant linear correlation $(\mathrm{R}=0.40)$ with acceptance, and therefore, texture was not an attribute relevant to the acceptance of these mango varieties.
Most of the tasters considered ideal the sweetness of varieties Juazeiro 2 (59.6\%), Imperial (58\%), Ubá (56.3\%), Palmer (54\%), Joa (54\%), and Beta $(51.9 \%)$ (Figure 2A). Similarly, most of the consumers considered as ideal the acidity of varieties Imperial (64\%), Juazeiro 2 (59.6\%), Beta (59.6\%), Joa (58\%), and Palmer (52\%) (Figure 2B). Variety Juazeiro 2, although considered as ideal for sweetness and acidity by most tasters, had low sensory acceptance (Table 2).

Variety Roxa Embrapa 141, which had the lowest titratable acidity (Table 1 ), was considered as having acidity below the ideal by $50 \%$ of tasters (Figure 2B). This variety had low acceptance and purchase intention (Table 2), suggesting that pulp with very low acidity may not please consumers.
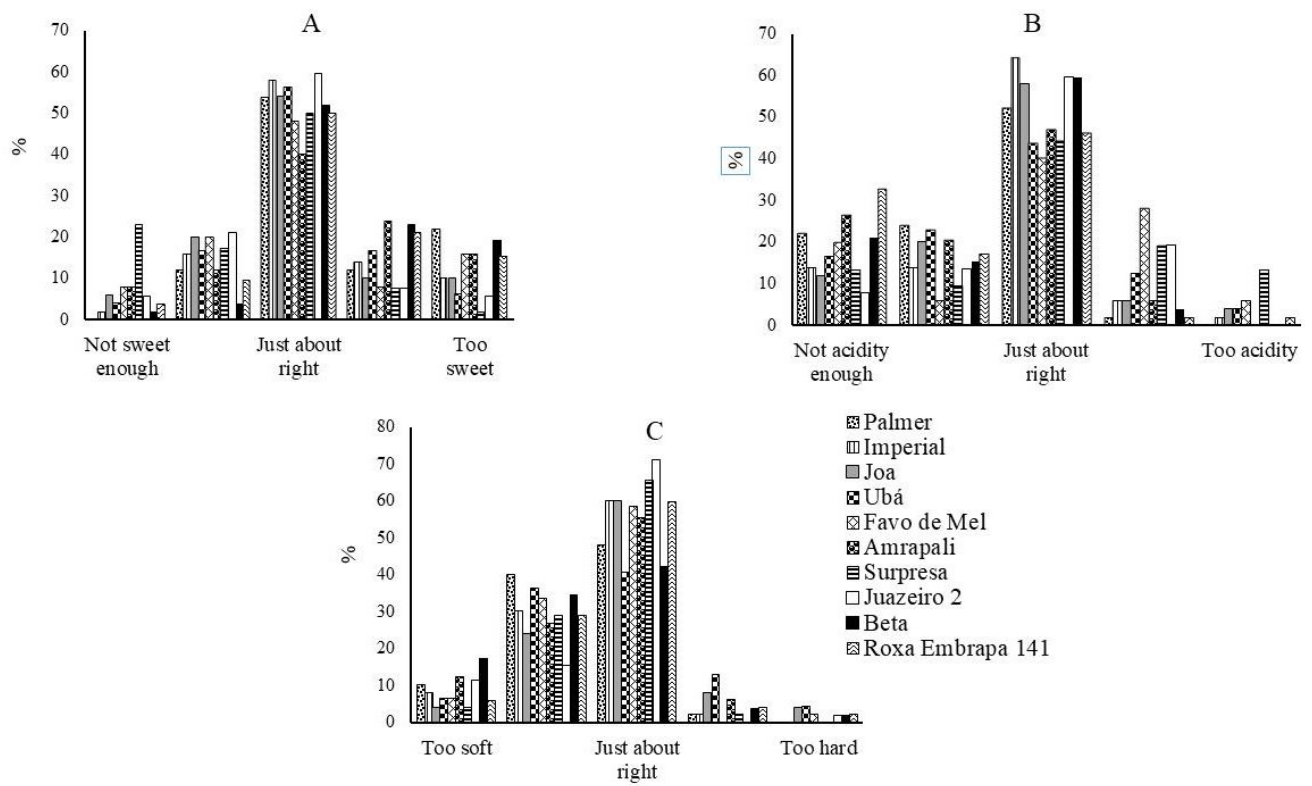

Figure 2. Just-about-right scale of mango varieties grown under the organic production system. A: sweetness; B: acidity; C: texture.

In general, tasters considered mango pulp firmness as ideal or softer than ideal, especially varieties Juazeiro 2 and Surpresa, which were considered as having an ideal firmness by 71.15 and $65.38 \%$ of the tasters, respectively (Figure 2C). However, these two varieties were not the most accepted (Table 2), probably because texture was not an attribute considered relevant to the acceptance.

The results of the sensory evaluation indicated that attributes sweetness and acidity of mango pulp are important but not determinant for its acceptance. Other chemical compounds that contribute to mango aroma and taste, but were not assessed in this study, could have a significant influence on the acceptance.

\section{CONCLUSION}

The characteristics soluble solids, total carotenoids, fruit mass, titratable acidity, $\mathrm{h}^{*}$ and $\mathrm{L}^{*}$ are considered the most important to differentiate the mango varieties evaluated. Imperial, Palmer, Beta and Joa varieties were the most accepted for all sensory attributes.

\section{ACKNOWLEDGMENTS}

To Bioenergia Orgânicos for the financial support. 


\section{REFERENCES}

BAKSHI, P. et al. Variability in physico-chemical and sensory attributes of mango genotypes under rainfed conditions of Shivalik Foothills of Himalayas. The Asian Journal of Horticulture, 8: 39-42, 2013

BATISTA, P. F. et al. Quality of different tropical fruit cultivars produced in the Lower Basin of the São Francisco Valley. Revista Ciência Agronômica, 46: 176-184, 2015.

BRASIL, Ministério da Agricultura Pecuária e Abastecimento. (2018). Instrução Normativa $\mathbf{n}^{\circ}$ 37, de 1 de outubro de 2018. Disponível em: $<$ http:// www.agricultura.gov.br>. Acesso em: 10 jan. 2020.

CARDOSO, P. C. et al. Vitamin C and carotenoids in organic and conventional fruits grown in Brazil. Food Chemistry, 126: 411-416, 2011.

CARVALHO, C. R. L. et al. Avaliação de cultivares de mangueira selecionadas pelo instituto agronômico de Campinas comparadas a outras de importância comercial. Revista Brasileira de Fruticultura, 26: 264-271, 2004.

CRUZ, C. D. Programa Genes: aplicativo computacional em genética e estatística. Viçosa, MG: UFV, 1997. 442 p.

FiBL - Research Institute of Organic Agriculture. The world of organic agriculture- statistic and emerging trends. Disponível em: https:// orgprints.org/37018/1/willer-lernoud-2019-world-oforganic-low.pdf. Acesso em: 01 fev. 2020.

FOLEGATTI, M. J. et al. Processamento e produtos. In: GENÚ, P. J. C.; PINTO, A. C. Q. (Eds). A cultura da mangueira. Brasília, DF: Embrapa Informação Tecnológica, 2002. p. 407-431.

GENTILE, C. et al. Food quality and nutraceutical value of nine cultivars of mango (Mangifera indica L.) fruits grown in Mediterranean subtropical environment. Food Chemistry, 277: 471-479, 2019.

IBGE- Instituto Brasileiro de Geografia e Estatística (2019). Produção Agrícola Municipal. Disponível em: <http://www.sidra. ibge.gov.br>. Acesso em: 15 mar. 2019.

LAWSON, T. et al. Characterization of Southeast Asia mangoes (Mangiferaindica $\mathrm{L}$ ) according to their physicochemical attributes. Scientia Horticulturae, 243: 189-196, 2019.

LIU, F. X et al. Physico-chemical and antioxidant properties of four mango (Mangifera indica L.) cultivars in China. Food Chemistry, 38: 396-405, 2013.

MEILGAARD, M.; CIVILLE, G. V; CARR, B. T. Sensory Evaluation Techniques, 3.ed. Boca Raton, Florida: Taylor and Francis, 1999. 416 p.

NTSOANE, M. L. et al. Quality assessment and postharvest technology of mango: A review of its current status and future perspectives. Scientia Horticulturae, 249: 77-85, 2019.

OLIVEIRA, A. R. et al. Cultivo da Mangueira. 2. ed. Petrolina, SE: Embrapa Semiárido, 2010. 111 p.

OLIVEIRA, L. A. Manual de laboratório: análises físico-químicas de frutas e mandioca. Cruz das Almas, BA: Embrapa Mandioca e Fruticultura, 2010. $248 \mathrm{p}$.

PALEI, S. et al. A studyon elite mango genotypes in Odisha- an avenue for crop improvement. Journal of Agriculture Science and Technology, 6: 269-273, 2016.

PAOLETTI, F. Chemical Composition of Organic Food Products. In: CHEUNG, P. C. K; MEHTA, B. M. (Eds.). Handbook of Food Chemistry, Berlin: Springer, 2014. p. 1-25.

RAMALLO, L.A.; MASCHERONI, R. H. Quality evaluation of pineapple fruit during drying process. Food and Bioproducts Processing, 90: 275-283, 2012.

RIBEIRO, S. M. R. et al. Antioxidant in mango (Mangifera indica L.) pulp. Plant Foods for Human Nutrition, 62: 13-17, 2007.

RODRIGUEZ-AMAYA, D., KIMURA, M. Harvest plus hand book for carotenoid analysis. IFPRI 332 and CIAT: Washington, DC and Cali. 2004.

ROTHMAN, L., PARKER, M. J. Just-About-Right (JAR) scales: design, usage, benefits and risks. West Conshohocken PA: ASTM International. 2009. $120 \mathrm{p}$.

RUFINI, J. C. M. et al. Caracterização biométrica e físico-química dos frutos de acessos de manga Ubá. Revista Brasileira de Fruticultura, 33: 456-464, 2011.

RUMAINUM, I. M. et al. Fruit quality and antioxidant capacity of six Thai mango cultivars. Agricultural and Natural Research, 52: 208-214, 2018 .

SABIR, I. A. et al. Trade potential evaluation of indigenous and exotic mango genotypes through 
physico-chemical and sensory attributes. Sarhad Journal of Agriculture, 34: 1-9, 2018.

SIVAKUMAR, D., JIANG, Y., YAHIA, E. M. Maintaining mango (Mangifera indica L.) fruit quality during the export chain. Food Research International, 44: 1254-1263, 2011.

STATSOFT. Statistics for Windows 7.0. Tulsa, OK: STATSOFT, 2008.

ZENEBON, O.; PASCUET, N. S.; TIGLEA, P. Métodos físico-químicos para análise de alimentos. 5. ed. São Paulo, SP: Instituto Adolfo Lutz, 2008. 1020 p. 